\section{Science and Religion in Dynamic Interplay $^{1}$}

\section{TODD SMITH}

\section{Abstract}

This paper proposes an approach to conceptualizing and contributing to the harmony of science and religion. In an effort to find points of unity that can serve as a basis upon which to advance the discourse on the subject, it begins by considering some of the legitimate concerns many thinkers have with religion and correlating them with the teachings of the Bahá'í Faith. With these correlations in mind, it then describes how it may be fruitful to think about both science and religion as viable sources of knowledge in their own right. Based on these descriptions, the balance of the paper focuses on three ways in which science and religion can be understood to complement each other: how they supplement each other, how they correspond to each other, and how they cultivate each other. Within this framework, a series of propositions are adduced for further inquiry.

1 I would like to thank Elham Afnan, Vargha Bolodo-Taefi, Omid Ghaemmaghami, Michael Karlberg, Mateen Navidi, Brett Smith, Sandra Smith, Matthew Weinberg, and the editorial team at the Journal for Bahá 'í Studies for their encouragement and helpful advice at various stages in the drafting of this paper.

\section{Résumé}

L'auteur de ce document propose une approche permettant de conceptualiser l'harmonie entre la science et la religion et de contribuer à sa réalisation. Afin de cerner des points de convergence pouvant servir de base pour faire avancer le discours sur le sujet, l'auteur commence par examiner certaines des préoccupations légitimes que de nombreux penseurs ont à l'égard de la religion, puis il met celles-ci en corrélation avec les enseignements de la foi bahá'íe. En gardant ces corrélations à l'esprit, l'auteur décrit en quoi il peut être profitable de considérer la science et la religion comme étant toutes deux des sources de connaissances viables. Sur la base de ces descriptions, l'auteur s'attarde ensuite sur trois façons dont la science et la religion peuvent être vues comme complémentaires l'une de l'autre : comment elles se suppléent, se correspondent et s'enrichissent mutuellement. Dans ce cadre, une série de propositions sont présentées aux fins d'un examen plus approfondi.

\section{Resumen}

Este artículo propone un enfoque para conceptualizar y contribuir a la armonía de la ciencia y la religión. En un esfuerzo por encontrar puntos de unidad que puedan servir como base sobre la cual avanzar el discurso sobre el tema, comienza considerando algunas de las preocupaciones legítimas que muchos pensadores tienen con la religión y correlacionándolas con las enseñanzas de la Fe Bahá'í. Con estas correlaciones en mente, describe cómo puede ser fructífero pensar tanto en la ciencia como en la religión como fuentes viables de conocimiento por derecho propio. Con base en estas descripciones, el resto del documento se centra en tres formas en que la ciencia y la religión pueden entend- 
erse para complementarse entre sí: cómo se cumplen; cómo se corresponden entre sí; y cómo se cultivan mutuamente. Dentro de este marco de referencia, se presentan una serie de proposiciones para consultas adicionales.

In his Hasan M. Balyuzi Lecture presented at the fortieth annual conference of the Association for Bahá'í Studies, Farzam Arbab argues that "[a] rigorous process of inquiry is needed to understand the nature of harmony between science and religion and the ways in which they complement each other in the civilization-building process" ("Intellectual Life" 19). He continues by underscoring that "the more attention we give to such an inquiry, and the sooner we begin doing so, the greater the progress we will achieve in the development of the intellectual life of the community" (19). This paper is an attempt to contribute to this process of inquiry and proposes the following approach to conceptualizing the ways in which science and religion complement each other.

The proposed approach is to first reflect on why it is that many are disaffected with religion and see it as being in conflict with science and devoid of value; to next articulate working - but not rigid - descriptions of both science and religion as "systems of knowledge and practice" (Universal House of Justice, 2 March 2013); and to then posit various ways in which science and religion, as articulated, are complementary. Here, the specific proposal is to consider how science and religion supplement (add to, compensate for, make up for the limitations of) each other, how they correspond to (reflect, overlap with, converge with, interface with) each other, and how they cultivate (nourish, fortify) each other while also contributing to the generation of knowledge and the betterment of humankind in their respective spheres. This last part is divided into two sections: how religion cultivates the development of science, and how science cultivates the development of religion.

In developing this approach, a series of propositions are advanced as suggested points of departure for further inquiry. No claim is made that any of these hypotheses are fully addressed or validated in this paper. There is not, for example, enough space to examine the relevant contributions of many authors who have taken up at least some of these matters. Rather, the main objective in advancing these propositions is to provide an outline of what the overall approach to understanding the harmony of science and religion could entail in light of the writings of the Bahá'í Faith, and how such an approach could help to address many of the criticisms that are legitimately raised by various proponents of materialism, among other thinkers.

Shoghi Effendi envisions that in a united world, "science and religion, the two most potent forces in human life, will be reconciled, will cooperate, and will harmoniously develop" (World Order 204). The central conviction informing this paper is that the relationship between science and religion 
in their true forms can be understood to consist of a unity in diversity of investigation and application. In other words, these two systems of knowledge are in dynamic interplay with each other, they sustain each other, and they serve as evolving reference points for each other while also pursuing their distinct agendas. One can think in terms of Hans-Georg Gadamer's concept of the "fusion of horizons," where different systems of knowledge mature through an ongoing interchange that challenges their respective preconceptions, opens up new vistas of understanding, and thereby leads to their reciprocal enrichment without necessarily compromising that which is core to each of them.

\section{The Disaffection with Religion}

In an effort to articulate the dynamic relationship between science and religion, and in line with Shoghi Effendi's admonition that we be "able to discuss intelligently, intellectually, the present condition of the world and its problems," it is important to consider how the teachings of the Bahá'í Faith correlate with "the current thoughts of the leaders of society" (Compilation no. 400) - to find points of unity that can form a basis upon which to advance the discourse on this topic. With this in mind, this section considers some of the critical thinking within the Western tradition pertaining to religion itself under the subheadings "Some Critical Concepts of Religion," "Understanding the Criticism of Religion," and "Making Sense of Humanity's Ills." It is anticipated that further research on this topic, and indeed on the subject of the harmony of science and religion more specifically, will benefit enormously from considering insights from Eastern and other traditions as well.

\section{Some Critical Concepts of RELIGION}

In October 1999, author Salman Rushdie published an article, "Imagine There's No Heaven," just as the population of the world was reaching six billion people. He addressed it specifically to the six-billionth world citizen, warning the child about the dangers of religion. It is worth quoting a few sentences from his article as they clearly encapsulate some of the thinking about religion today:

Living religions ... will be called the heart of your culture, even of your individual identity.

It is possible that they may at some point come to feel inescapable, not in the way that the truth is inescapable, but in the way that a jail is.

As human knowledge has grown, it has also become plain that every religious story ever told about how we got here is quite simply wrong. This, finally, is what all religions have in common. They didn't get it right.

To choose unbelief is to choose mind over dogma, to trust in our humanity instead of all these dangerous divinities. 
Only you can decide if you want to be handed down the law by priests, and accept that good and evil are somehow external to ourselves.

Since the dawn of the Enlightenment, and particularly since the rise of the philosophes such as Voltaire and Diderot, there has been an increasing disaffection with religion, especially among social thinkers. Many have come to see religion as detrimental, delusional, or both, as Rushdie describes it. Perhaps the most famous claim along these lines is Karl Marx's assertion that religion "is the opium of the people" (115), although his project is not so much concerned with addressing the problem of religion head on. Instead, he is intent on overturning the capitalist mode of production in which religion plays the ameliorative role of sustaining the proletariat and giving meaning to their lives in the face of exploitative and alienating conditions. As far as he is concerned, once capitalism gives way to communism, as is humanity's destiny, religion, "the sigh of the oppressed creature" (115), will lose its grip on human consciousness.

A host of other thinkers have criticized religion or defined it in terms alien to those who view themselves as religious. One of the more well-known among them is Ludwig Feuerbach, Marx's predecessor, who denies the existence of God and describes Him in anthropomorphic terms as nothing more than the projection of our idealized selves writ large. ${ }^{2}$ Another one is Friedrich Nietzsche, who despises what he sees as the herd mentality that humanity has fallen into and blames the Judeo-Christian tradition for giving birth to, and propagating, a slave morality inimical to human flourishing - a morality which must, therefore, be surpassed. Similarly, Soren Kierkegaard, a contemporary of Feuerbach, in his determination to in fact revitalize Christianity, argues that Christianity has become ritualized and superficial, is devoid of passion, commitment, and true faith, and thus suckles the mediocrity that one finds in every corner of society. He would have agreed wholeheartedly with the following passage where Shoghi Effendi quotes an American Presbyterian minister lamenting the state of the church: "If Christianity wishes and expects to serve the world in the present crisis, ... . it must 'cut back through Christianity to Christ, back through the centuries-old religion about Jesus to the original religion of Jesus"" (World Order 184).

More recent thinkers include the sociologist Peter Berger, who begins with the notion that humans are by nature unfinished beings. We have no species-specific essence, so we go about "finishing" ourselves by socially constructing our reality. In creating

2 An updated version of this theory is Nancy Ellen Abrams's view that God emerges out of human consciousness. As Paul Lample explains, she holds that the concept of God enables humanity "to establish unity and cooperation on a global scale" (42). 
and assigning meaning to our world and the phenomena within it, we compensate for our essential deficiencies. But we also conceal this process from ourselves, for otherwise we risk having to come to terms with the inessentiality and tenuousness of the way things are, the prospect of which is incredibly disconcerting. That is, we risk placing ourselves in a state of anomie.

To illustrate, Berger says that "[i]f one imagines oneself as a fully aware founder of a society, a kind of combination of Moses and Machiavelli, one could ask oneself the following question: How can the future continuation of the institutional order, now established ex nihilo, be best ensured?" (33). One could employ all the power at one's disposal, but there "still remains" what he calls "the problem of legitimation, all the more urgent because of the novelty and thus highly conscious precariousness of the new order" (33). The solution, Berger says, is religion, because it "legitimates social institutions by bestowing upon them an ultimately valid ontological status, that is, by locating them within a sacred and cosmic frame of reference" (33).

Others take a darker view of religion and argue, as Rushdie does, for its eradication. For neo-Darwinists such as Jerry A. Coyne, Richard Dawkins, Daniel C. Dennett, and Christopher Hitchens, religion has no redeeming value. In the first place, it is irrational, has no basis in logic or reality, and is antithetical to science generally and evolutionary theory specifically. In the second place, it is the source of fanaticism and the cause of much of the needless suffering that afflicts humanity. There are, additionally, a host of other reasons why they believe religion is defective-including, in their view, inadequate proofs for the existence of God, religion's inability to explain evil and suffering, and so on-but suffice it to say that, for them, there would be nothing better than for religion to wither away and die in order to clear the path, once and for all, for science, or secular, rational thought more generally, to lead humanity to a brighter future. ${ }^{3}$

\section{UNDERSTANDING THE CRITICISM OF RELIGION}

Obviously, the Bahá'í view of religion is very different and has much to say about how such critical views are constrained by materialist assumptions, ${ }^{4}$ some of which are discussed below. At the same time, denunciations of religion are surely understandable given what has been done in its name. As the House of Justice explains, "The rigid intolerance exhibited in the past by much of organized religion, together with the domination of scholarship long exercised by theological elites,

3 For an overview of additional reasons why some dispute the harmony between science and religion, see John Hatcher's introduction to One Reality: The Harmony of Science and Religion (Taylor and Hatcher).

4 For additional views on how religion has been perceived, see Lample (38-42). 
could not but arouse strong negative reactions" (20 July 1977).

Indeed, a number of social phenomena, when studied on their own, support the conclusion that religion is problematic, if not dangerous or bankrupt. Among these are the following six. ${ }^{5}$ First, the increasing awareness throughout the world of the existence of a variety of expressions of, and perspectives on, religion, which has naturally raised legitimate questions about what constitutes a viable guide to life. Second, the perception that religious beliefs fall short of addressing the practical and moral issues of today, and that there is accordingly an unresolvable mismatch between religion and modernity (or postmodernity) that renders the former anachronistic. Third, the conspicuous differences and antipathy between many religious communities and factions, notwithstanding the efforts of some to promote tolerance and pluralism. Fourth, the unseemly conduct of various religious leaders and institutions. Fifth, the horrid violence and destruction carried out in the name of religion by some fanatical groups. And sixth, the distortion of the central tenets of the various world religions by leaders who cling tenaciously to their orthodoxies, impose their interpretations on their congregations, and thus stifle the independent investigation of truth while concurrently sanctioning dogmatism, superstition, and factionalism.

5 One can find such themes in One Common Faith and the message of the Universal House of Justice to the world's religious leaders dated April 2002.
Bahá'ís certainly agree that religion can be problematic in these ways and that, when so, we are better off without it. Regarding the first two social phenomena, Shoghi Effendi states that "[i]f long-cherished ideals and time-honored institutions, if certain social assumptions and religious formulae have ceased to promote the welfare of the generality of mankind . . . let them be swept away and relegated to the limbo of obsolescent and forgotten doctrines" (World Order 42). As to the third, fourth, and fifth, one is reminded of 'Abdu'l-Bahá's warning "that religion must be the source of fellowship, the cause of unity and the nearness of God to man. If it rouses hatred and strife, it is evident that absence of religion is preferable and an irreligious man better than one who professes it" (Promulgation 181). And concerning the sixth, Paul Lample explains: "When the teachings of religion are distorted in this way, religions depart from what is true, what is good, and what is right, to become the imposition of ideology and the exercise of power over others" (26). Bahá'u'lláh Himself warns of this phenomenon as it relates to recognizing the Manifestation of God. In the Kitábi-Íqán, He states:

Leaders of religion, in every age, have hindered their people from attaining the shores of eternal salvation, inasmuch as they held the reins of authority in their mighty grasp. Some for the lust of leadership, others through 
want of knowledge and understanding, have been the cause of the deprivation of the people. (15)

\section{Making Sense of Humanity's ILls}

Such criticisms of religion can be understood as part of a larger effort to make sense of the social ills that currently plague humanity - a humanity that, from a Bahá'í perspective, is not yet attuned to the spiritual springtime that has taken root with the Revelation of Bahá'u'lláh. One might argue that the abovementioned critics and others (unwittingly) offer valuable insights into humanity's spiritual decline (and, more recently, into the forces of disintegration currently at work in the world today), when the divine impulse of the previous Revelation is exhausted, moral vitality and social cohesion are everywhere diminished, religion as practiced "loses its relevance" (Bahá'í International Community 26), and "uncertainty about the meaning and value of life generates anxiety and confusion" (26-27). From this vantage point - one shared by many proponents of materialism and neo-Darwinism, among other thinkers-religion has done little, if anything, to lift humanity out of its current plight.

Consistent with the writings of the Bahá'í Faith, many have also claimed that humanity is rife with social disease pernicious to the human condition. Notably, these include some of the influential thinkers mentioned above who lived during the lifetimes of the Báb and Bahá'u'lláh. The early Marx, for example, condemns the capitalist mode of production for promoting increasing specialization and the mindless repetition of gradually simplified, mechanized tasks. Within this mode, he argues, the individual becomes alienated from the production process, from the product itself, from his or her fellow workers, and finally, from his or her creative self-all forms of fragmentation. Most atrophy under such conditions; rarely do they exceed mediocrity.

Nietzsche despises such mediocrity and vigorously promulgates the affirmation of life in the face of what he perceives to be a nihilistic society. $\mathrm{He}$ loathes conformity, ordinariness, and the totalizing theories that justify them. $\mathrm{He}$ derides entities like the modern state "where everyone, good and bad, is a poison drinker: the state where everyone, good and bad, loses himself: the state where universal slow suicide is called-life" (Zarathustra 77). Instead, Nietzsche venerates the free spirit, the one able to devise his or her own path. He reveres the one who can create, the constructor who can cut free from the shackles of normalness, the anti-superfluous one. Where Nietzsche strays, at least from a Bahá'í perspective, is with his extreme individualism, his rejection of the existence of God, and his repudiation of anything that purports to transcend a dynamic relationship with the earth and the will to power that permeates every element and being (a positive, creative force, in his mind). This worldview is part of Nietzsche's response to the cultural sickness he saw around him which, as 
Raymond Geuss explains, he judged in a similar way to a host of other thinkers:

The diagnosis was that life in the modern world lacks a kind of unity, coherence, and meaningfulness that life in previous societies possessed. Modern individuals have developed their talents and powers in an overspecialized, one-sided way; their lives and personalities are fragmented, not integrated, and they lack the ability to identify with their society in a natural way and play the role assigned to them in the world wholeheartedly. They cannot see the lives they lead as meaningful and good. Schiller, Hölderlin, Hegel, Marx, Wagner, Nietzsche (and many other lesser-known figures) all accept versions of this general diagnosis. (49)

So does Kierkegaard. In his words: "The present age is essentially a sensible, reflecting age, devoid of passion, flaring up in superficial, short-lived enthusiasm and prudently relaxing in indolence" (252).

In short, for these thinkers, alienation, complacency, averageness, cynicism, despair, and a herd mentality are the norm, perhaps interspersed with fleeting bursts of zeal. One sees clear similarities with Shoghi Effendi's assessment of the state of the world:

Sore-tried and disillusioned, humanity has no doubt lost its orientation, and would seem to have lost as well its faith and hope. It is hovering, unshepherded and visionless, on the brink of disaster. A sense of fatality seems to pervade it. An ever-deepening gloom is settling on its fortunes as it recedes further and further from the outer fringes of the darkest zone of its agitated life and penetrates its very heart. (World Order 190)

Similar concerns have also been raised in the twentieth and twenty-first centuries, producing a wealth of thoughtful analyses, some features of which likewise correlate well with assessments found in the writings of the Bahá'í Faith. Georg Simmel argues that with the emergence of modern urban society-which, in certain respects, has been positive-people have become more aloof and indifferent, adopting a blasé attitude that has been exacerbated by the leveling culture of money that pervades the metropolis and causes human beings to see each other in terms of their rational utility. Max Weber maintains that a process of rationalization has come to permeate and regulate every aspect of our lives, resulting in an iron cage from which there is no real escape - that is, a world dominated by efficiency, order, and calculability, and one bereft of meaning, moral direction, and any sense of the mystical (Kalberg). Hannah Arendt claims that we have become mechanical creatures due to bureaucratic administration, technological leveling, and scientism, which includes the view that human 
beings can be fully understood in physical and natural terms alone. We, moreover, spend the bulk of our time in "labor" (taking care of our biological needs) rather than "work" (producing enduring artifacts) and "action" (participating in meaningful political discourse), the latter of which promotes our "natality"- the ever-present possibility for each individual to offer the world something new and unexpected. Others, such as Ulrich Beck, see us as troubled by the notion that we have, through our science and technology, created unprecedented global risks, and as being paralyzed in the face of potential crises: nothing seems fixed to us anymore; all seems uncertain and insecure. Charles Taylor, moreover, sees this anxiety, torpor, and longing for a motivating pattern of life as tied to the growing disenchantment with the world - the sense that life is now devoid of spiritual or mystical significance-a phenomenon first recognized by the Romantics, and one that is correlated with the rise of instrumental reason, which has produced fragmentation among humans in three fundamental ways: "within themselves, between themselves, and from the natural world" (94). And the list goes on - to say nothing, for example, of the legitimate preoccupation that many theorists have with the culture of contest and conflict, the tribalism, the worsening state of the environment, the resurgence of overt forms of prejudice, the palpable disparity between the rich and the poor, the displacement of populations, and the deadening effects of consumerism that are everywhere apparent. ${ }^{6}$

This is not to deny that humanity has progressed in many ways. Thinkers such as Johan Norberg, Steven Pinker, and Hans Rosling have all reasonably argued that life is much better for us now than it was in the past when one considers such factors as overall health, life expectancy, equality, and human rights. It is also not to deny that the spiritual impulse can endure in the face of the forces of fragmentation, contest, consumerism, and the like that work to undercut it. ${ }^{7}$ Yet, these qualifications notwithstanding, it seems reasonable to conclude that the forces of fragmentation and the turmoil that attends it exert a powerful sway over our psyches today, that they disempower us, and that, we might add, consumerism itself, not religion, has become the "opium to the human soul" (Universal House of Justice, 2 March 2013). ${ }^{8}$ Indeed, it is not much of a stretch to suggest that many would sympathize with the following assessment by the House of Justice regarding the despair that currently vexes human consciousness: "Ill-equipped to interpret the social commotion at

6 A few examples of such thinkers are Paul Hanley, Naomi Klein, Herbert Marcuse, and Pankaj Mishra.

7 One Common Faith describes how the spiritual impulse is resurging in a diversity of forms (5-6).

8 This analysis does not consider the culture of contest that Michael Karlberg (Beyond) analyzes or the extensive conflict that exists owing to the fragmented mindset. 
play throughout the planet, they listen to the pundits of error and sink deeper into a slough of despond. Troubled by forecasts of doom, they do battle with the phantoms of a wrongly informed imagination" (Riḍván 1999). Within such a perplexing culture, we obfuscate our true potential to achieve lofty heights as a species. We participate in a moribund order and perpetuate a way of being that "is weary for want of a pattern of life to which to aspire" (Universal House of Justice, Riḍván 2012).

\section{WORKING DESCRIPTIONS OF RELIGION AND SCIENCE}

The aim thus far has been to provide insights into why many repudiate religion and to consider why their criticisms are, in many cases, a reasonable reaction to the state that religion has apparently fallen into and its seeming impotency to grapple with the ills afflicting the world. More than that, the aim has been to identify a number of points of unity, or correlations between such criticisms and the teachings of the Bahá'í Faith, which can serve as a common foundation upon which to further explore the relationship between science and religion. Hopefully, the foregoing has been helpful in this regard, although many other criticisms have not been addressed such as some of the more scientific and philosophical ones pertaining to evolution, proofs of the existence of God, the problem of evil, and the suffering of innocents.

Having established a number of correlations as a foundation, the next step is to offer an account of how to think about religion and science. The proposition here is that while it makes sense to question the harmony between science and religion in view of the observations about religion discussed above, these observations invariably miss the mark because they are premised on a misunderstanding of what religion truly is. In other words, the criticisms raised by materialists and others are admittedly germane and understandable insofar as they expose veritable failings of religion as currently practiced in many settings. However, as 'Abdu'l-Bahá states, Bahá'u'lláh has "reconciled science with religion by revealing the pure teachings of the divine reality" (Promulgation 231).

Drawing on the Bahá'í writings, what follows, therefore, is an attempt to outline some of the core features of religion, albeit without claiming they add up to an actual definition of religion. Also briefly considered are some of the predominant features of science. It is proposed that with these features in mind, we can more readily explore how to approach the relationship between these two systems of knowledge and practice. ${ }^{9}$

9 In taking this approach, it is recognized that the nature of religion and the nature of science are vast subjects on their own that have received sustained attention within various fields of study. It is impossible to engage with the plethora of theories pertaining to each in this paper. For interested readers, good places to start 
RELIGION $^{10}$

As stated by Bahá'u'lláh, the purpose of religion is twofold: "The first is to liberate the children of men from the darkness of ignorance, and guide them to the light of true understanding. The second is to ensure the peace and tranquillity of mankind and provide all the means by which they can be established" (Gleanings 34:5). Religion is the motivating impulse that impels both individual and social advancement.

Specifically, religion is the primary agent of the spiritual development of humankind (One Common Faith 13). It is the means by which each of us is able to "know his Creator and to attain His presence" (Bahá'u'lláh, Gleanings 29:1) — the very purpose of life - although, owing to our human limitations, we can never know the essence of God, but only His attributes, His signs, and His names. Further, within every one of us resides the essence of God's light. Religion refines our inner vision so that "we may perceive the glory of God" ('Abdu'l-Bahá, Promulgation 90) and obtain reunion with Him - the longing of every human soul.

There is only one God and knowledge of Him is made possible by recognizing His Manifestations and adhering

include Benjamin Schewel's Seven Ways of Looking at Religion: The Major Narratives and Peter Godfrey-Smith's Theory and Reality: An Introduction to the Philosophy of Science.

10 Lample also offers an outline of true religion. Many of his points have been incorporated into this section. to Their teachings. Through Their Revelations, "all the names and attributes of God, such as knowledge and power, sovereignty and dominion, mercy and wisdom, glory, bounty, and grace, are made manifest" (Bahá'u'lláh, Gleanings 19:3). By turning to these Manifestations and putting Their teachings into practice, we become empowered to fulfill our evolving responsibilities and develop our corresponding requisite capacities, which otherwise remain latent, inert, or stunted. The object of every Revelation "is to effect a transformation in the whole character of mankind, a transformation that shall manifest itself, both outwardly and inwardly, that shall affect both its inner life and external conditions" (Bahá'u'lláh, Kitáb-i-Íqán 169). When religion is "faithful to the spirit and example of the transcendent Figures," it awakens "in whole populations capacities to love, to forgive, to create, to dare greatly, to overcome prejudice, to sacrifice for the common good and to discipline the impulses of animal instinct" (Universal House of Justice, April 2002). Such religion "reaches to the roots of motivation." On the other hand, "whenever religious practice veers too far from this revelatory impulse, the tares of superstition, of idle fancies and vain imaginings take root in human hearts" (Lample 45).

There is in truth only one religion of God with the Message of each Manifestation revealing "a stage in the limitless unfolding of a single Reality" (One Common Faith 22), identified by Bahá'u'lláh as “the changeless Faith of 
God, eternal in the past, eternal in the future" (Gleanings 70:2). Each stage in this process of Progressive Revelation constitutes " "the City of God,' a source of knowledge that totally embraces consciousness" (One Common Faith 13), and is imbued with such potency as to endow the seeker with "a new eye, a new ear, a new heart, and a new mind" (Bahá'u'lláh, Gleanings 125:6). Each stage is thus a fulfillment of the Covenant that God has established with humanity whereby He reveals through His Messengers what is required of us to advance. Our role in this Covenant is to recognize His Messengers - these "Daysprings of Mercy" (Gleanings 139:2) — when They appear, and to abide by Their ordinances.

Every Revelation infuses new meaning into timeless spiritual truths, but also supplements these truths with social teachings, laws, and ordinances that address the requirements of the age. Together these spiritual and social teachings enable humanity to advance in stages towards the unification of the entire human race, which is "the hallmark of the age of maturity" (Universal House of Justice, 2 March 2013), and which, when achieved within the Dispensation of Bahá'u'lláh, will entail "an organic change in the structure of present-day society, a change such as the world has not yet experienced" (Shoghi Effendi, World Order 43). All religions teach us to see service to others as a moral duty, to treat others as we would treat ourselves, to love one another, and to foster peace and unity, and they admonish that if humanity fails to live in accordance with such teachings, it lapses into moral decline. At the same time, because "[e]very age hath its own problem ... [t] he remedy the world needeth in its present-day afflictions can never be the same as that which a subsequent age may require" (Bahá'u'lláh, Gleanings 106:1).

The dual nature of Progressive Revelation is linked to the twofold station of each Manifestation, one being the station of unity, and the other being the station of distinction. Regarding the former, all the Manifestations are to be viewed as "abiding in the same tabernacle, soaring in the same heaven, seated upon the same throne, uttering the same speech, and proclaiming the same Faith" (Bahá'u'lláh, Gleanings 22:3). Regarding the latter, the Manifestations appear "clothed in divers attire" owing to Their distinctive missions to help humanity advance in accordance with its capacity at the time of Their appearance.

Finally, the purpose of religion is to learn how to collectively, and systematically, apply the teachings of the latest Manifestation of God for the betterment of humankind. "For the Bahá'í community," Lample states, "the practice of true religion requires growing in capacity over time to translate Bahá'u'lláh's Teachings - His concept of religioninto systematic action as a remedy for the ills afflicting humanity" (50). As Sona Farid-Arbab further explains, religion "is based on revelation but elaborated through a continual process of learning through social interaction" (174). 


\section{SCIENCE}

Science is generally understood as a systematic endeavor that utilizes observation and experiment to study and organize knowledge regarding the nature and behavior of phenomena in the natural world. There is some debate over what, in fact, constitutes science as an enterprise - that is, what demarcates it from other forms of knowledge generation. However, it is relatively safe to say that science typically includes empirical observation, forming questions and hypotheses, deducing observational predictions from those hypotheses, gathering data and testing those predictions, analyzing the data and the experimental results, deriving and sharing conclusions as to the adequacy of the original hypotheses, developing broader theories and models about the phenomena in question that guide further research, and, where possible, advancing explanatory laws of nature. At different stages in the enterprise, various strategies are used, such as induction (drawing general conclusions from specific instances, or drawing generalizations beyond cases observed), abduction (finding the simplest or most likely explanation for a set of observations), deduction ${ }^{11}$ (moving from general principles to specific conclusions, or deducing observational predictions from hypotheses), verification (testing to see if a

11 Deductive logic more specifically deals with patterns of argument in which, for example, if the premises are true, it follows necessarily that the conclusion is true. hypothesis is true or justified), and falsification (testing a hypothesis with the objective of trying to refute it). Mathematics also plays a key role in certain scientific fields, serving as the primary tool or language to describe scientific findings.

There are many theories about how science works in practice and the extent to which, and the manner in which, its different tools are actually employed. Philosophers and sociologists of science, for example, raise questions about the relationship between scientific pursuits and social conditions; the power of paradigms, worldviews, language, preconceptions, and context to limit the process of discovery and justification; how systematic science truly is; how objective it truly is; how much of it is grounded in reason and empirical evidence versus intuition, imagination, and other "irrational" sources of inspiration; the extent to which the facts it uncovers are theory laden; whether or not it actually gets at reality as it is in itself (realism) or is simply an effective way of explaining observable phenomena (instrumentalism); and so on. There is no space to deal with these matters here, ${ }^{12}$ but some of them are alluded to in the discussion on the harmony of science and religion below. It merits emphasis, however, that from a Bahá'í perspective, science plays a central role in the progress of humanity. According to 'Abdu'l-Bahá,

12 For a clear overview of many of the issues involved, see Arbab ("An Inquiry" 136-48). 
science may be likened to a mirror wherein the infinite forms and images of existing things are revealed and reflected. It is the very foundation of all individual and national development. Without this basis of investigation, development is impossible. Therefore, seek with diligent endeavor the knowledge and attainment of all that lies within the power of this wonderful bestowal. (Promulgation 50)

\section{How Science AND Religion COMPLEMENT EACH OTHER}

With these features of religion and science in mind, what follows is an attempt to outline how these two systems of knowledge and practice are naturally harmonious - how, that is, they are dynamically related and how each, when divorced from the other, invariably falls into dogmatism and rigidity and becomes diminished in its ability to advance civilization. The specific thesis is that it is fruitful to explore the ways in which science and religion-understood from this point forward in accordance with how they are articulated above-complement each other by considering how they variously supplement, correspond to, and cultivate each other while also maintaining their autonomy as distinct areas of endeavor.

It should be acknowledged that this is a massive topic that deserves much more attention than can be given in a paper of this length, particularly in view of the valuable contributions of many notable thinkers on the subject—such as Ian G. Barbour, Samuel Gregg, Peter Harrison, John Haught, Alister E. McGrath, Nancy Murphy, John Polkinghorne, Jonathan Sacks, and many more- that are not taken into account. As just one example, it would be beneficial to consider how the approach suggested here relates to Barbour's four views of the relationship between science and religion: conflict, independence, dialogue, and integration. Consequently, what follows should be treated simply as a series of propositions or hypotheses. It is anticipated that these propositions will be subjected elsewhere to further testing and inquiry that will do much more to correlate the writings of the Bahá'í Faith with relevant current thought. In addition, most of the focus will be on a series of propositions regarding how science and religion cultivate each other, as this seems to be an area that has received little attention in the literature on the subject and is of particular relevance when considering the issues raised by materialists and other critics of religion. Here, a number of subpropositions are also advanced for further consideration.

\section{Proposition 1: \\ Science And Religion SuPPLEMENT EACH OTHER}

Although there is much to say about this proposition, it will be discussed only briefly because it is already generally accepted among advocates of the 
harmony of science and religion at least as far back in the Western tradition as Thomas Aquinas, who argues that humans come to know reality through both the natural light of reason and that of faith (Campbell and Looy, Section 2: Entries). It is further suggested that this proposition is often what is meant when it is argued that science and religion "complement" each other. In this respect, the statement One Common Faith provides the following description of the relationship between these two systems of knowledge and practice:

The one discerns and articulates the values unfolding progressively through Divine revelation; the other is the instrumentality through which the human mind explores and is able to exert its influence ever more precisely over the phenomenal world. The one defines goals that serve the evolutionary process; the other assists in their attainment. Together, they constitute the dual knowledge system impelling the advance of civilization. Each is hailed by the Master as an "effulgence of the Sun of Truth." (33)

To elaborate, each is considered a system of knowledge and practice in its own right. Religion explores the spiritual dimension of reality, often referred to as the Book of Revelation, and science explores the material dimension, often referred to as the Book of Creation or the Book of Nature.
Neither is sufficient to render an adequate picture of reality because reality "is too complex to admit a single description" (Arbab, “An Inquiry” 136).

Instead, in order to come to increasingly comprehensive understandings of reality, two languages are needed..$^{13}$ These languages - or systems of investigation, understanding, communication, meaning, and practice-supplement-i.e., add to, compensate for, make up for the limitations of - each other in that together they provide a fuller picture of reality and its intricacies and possibilities in all their richness. Science focuses on natural, psychological, and social phenomena, and seeks to uncover the laws, patterns, principles, or conditions governing, underlying, or contributing to their behavior. Religion investigates spiritual verities; moral archetypes; the nature of the individual's relationship to his or her Creator, fellow human beings, and the rest of creation; and the evolving laws, ordinances, and ethical provisions required for humanity to advance towards realizing its inherent oneness. Both seek to translate, where possible, their respective findings into tangible, useful realities - to apply them for human betterment. Referring to them as two kinds of science, 'Abdu'l-Bahá offers the following description of their respective pursuits and the vital necessity of each:

13 Sona Farid-Arbab's Chapter 6 ("Complementarity") provides a cogent analysis of this very theme. 
Scientific knowledge is the highest attainment upon the human plane, for science is the discoverer of realities. It is of two kinds: material and spiritual. Material science is the investigation of natural phenomena; divine science is the discovery and realization of spiritual verities. The world of humanity must acquire both. A bird has two wings; it cannot fly with one. Material and spiritual science are the two wings of human uplift and attainment. Both are necessaryone the natural, the other supernatural; one material, the other divine. By the divine we mean the discovery of the mysteries of God, the comprehension of spiritual realities, the wisdom of God, inner significances of the heavenly religions and foundation of the law. (Promulgation 138)

Science and religion are also supplementary in that each sheds light on different aspects of certain phenomena, thus providing deeper insight into such phenomena and greater ability to penetrate their mysteries. An example of this is what it means to be human and to achieve human potential. Focusing on only one or another aspect of the human condition gives a reductionistand, therefore, skewed - understanding of it. This, as Lample explains, is particularly clear in the case of consciousness and related human capacities. Correlating the work of Thomas Nagel and John Searle with the Writings and utterances of 'Abdu'l-Bahá,
Lample argues that "[s]cience, freed from a reductionistic lens, can go far in exploring the expression of such potentialities" (36). "Yet, for Bahá'ís," he continues, "science and reason alone cannot fully exhaust such possibilities; this is where religion is needed, to address and cultivate certain capacities with which the human being is endowed" (36). In this regard, Shoghi Effendi explains that without religion,

Human character is debased, confidence is shaken, the nerves of discipline are relaxed, the voice of human conscience is stilled, the sense of decency and shame is obscured, conceptions of duty, of solidarity, of reciprocity and loyalty are distorted, and the very feeling of peacefulness, of joy and of hope is gradually extinguished. (World Order 187)

The issue of reductionism is discussed in greater depth later, under Proposition 3.

It is tempting to additionally argue that science and religion supplement each other in the way that the left and right hemispheres of the brain supplement each other. This is the position that Rabbi Jonathan Sacks takes in his book The Great Partnership:

Science is about explanation. Religion is about meaning. Science analyses, religion integrates. Science breaks things down to their component parts. Religion binds people together in relationships 
of trust. Science tells us what is. Religion tells us what ought to be. Science describes. Religion beckons, summons, calls. Science sees objects. Religion speaks to us as subjects. Science practises detachment. Religion is the art of attachment, self to self, soul to soul. Science sees the underlying order of the physical world. Religion hears the music beneath the noise. Science is the conquest of ignorance. Religion is the redemption of solitude. (Introduction)

While his book is very helpful in understanding the need for religion and science to work together in order for humanity to prosper, the partnership Rabbi Sacks rightly advocates is arguably more complex and interactive than he describes. Many of the distinctions he draws seem too sharp. This takes us to the next proposed way in which science and religion complement each other.

\section{Proposition 2:}

SCIENCE AND Religion CoRRESPOND TO ЕACH OTHER

Religion is certainly concerned with meaning, human relationships, redemption, and what ought to be, while material science is arguably not concerned with such issues (although some may contend otherwise in the case of human relationships, as alluded to below). However, religion also explains reality, providing many insights into the nature of what is. Some Answered Questions and the Tablet to Auguste Forel are full of such explanations, as are many of the other Writings of 'Abdu'l-Bahá and of Bahá'u'lláh Himself. Moreover, while science does indeed break things down and describe them, it also attempts to synthesize its findings into coherent understandings of reality. The perennial search for an equation in physics that explains everythingthat, for instance, reconciles quantum physics and the theory of relativity in a manner so simple it can be explained on a t-shirt (Falk) - is just one example. Both science and religion, moreover, are about the conquest of ignorance. As quoted earlier, God sends His Messengers to "liberate the children of men from the darkness of ignorance" (Bahá'u'lláh, Gleanings 34:5). In these ways, science and religion go beyond supplementing one another. The proposition here is that they also correspond to-i.e., overlap or converge withone another in a number of other ways, including "the questions they address and the methods they employ" (Arbab, "An Inquiry" 135).

\section{Questions}

In terms of the questions they address, they both shed light on some of the same features of reality. In other words, science and religion are concerned with realities that are ontologically the same or at least intimately connected. In Some Answered Questions, 'Abdu'l-Bahá states: "Religion, then, consists in the necessary relationships deriving from the reality of things" (41:9). In the Tablet to Auguste 
Forel, He states: "By nature is meant those inherent properties and necessary relations derived from the realities of things. And these realities of things, though in the utmost diversity, are yet intimately connected one with the other" (para. 15).

To elaborate, science and religion, for the most part, now converge ${ }^{14}$ in their recognition that, notwithstanding their diversity, human beings are, at their core, the same. As stated by the House of Justice: "World order can be founded only on an unshakable consciousness of the oneness of mankind, a spiritual truth which all the human sciences confirm. Anthropology, physiology, psychology, recognize only one human species, albeit infinitely varied in the secondary aspects of life" (October 1985). They similarly converge on the notion that the universe itself is interconnected, a central tenet of Buddhism, Hinduism, and the Bahá'í Faith, among other religions. According to 'Abdu'l-Bahá, "every part of the universe is connected with every other part by ties that are very powerful and admit of no imbalance, nor any slackening whatever" (Selections 137:2). Physics, as already mentioned, is on a quest to explain the interconnections of the universe as succinctly as possible. One prominent theory today holds that space itself is an interlinkage of individual quanta of gravity such that "the world seems to be less about objects

14 The extent to which, and how, science and religion converged in the past is not addressed here but warrants attention in fleshing out this proposition. than about interactive relationships" (Rovelli 43), thus questioning the longstanding materialist notion that matter is the essential basis of reality. Environmental science likewise highlights the web of connections between nature and human beings and the deleterious consequences of our having ignored them. Arne Naess was an early proponent of this view. In addition, science and religion are both helping us to understand the characteristics of beneficial human relationships. Religion is obviously concerned with this. There is also a growing body of research highlighting the advantages of altruism, sharing, and cooperation. Relevant thinkers in this regard include Robert Axelrod, Natalie and Joseph Henrich, Thomas Nagel (Possibility of Altruism), and Martin Nowak.

\section{Reason, Method, Imagination, and Models}

Another way in which science and religion seem to correspond to each other is that they employ comparable criteria and methods when attempting to understand various features of reality and to advance their respective enterprises. Both resort to reason for justification. 'Abdu'l-Bahá explains: "If we say religion is opposed to science, we lack knowledge of either true science or true religion, for both are founded upon the premises and conclusions of reason, and both must bear its test" (Promulgation 107).

At the same time, both rely on intuition, creativity, and imagination to advance their respective projects. This 
may be obvious in the case of religion, but it is also true of science. The House of Justice states that when engaging in scholarship, we should "strive to develop ... respect for a wide range of approaches and endeavours" (Compilation no. 380). Paul Feyerabend emphasizes the importance of such flexibility as it relates to the scientific method in particular. He says:

Indeed . . . events and developments, such as the invention of atomism in antiquity, the Copernican Revolution, the rise of modern atomism ... [and] the gradual emergence of the wave theory of light, occurred only because some thinkers either decided not to be bound by certain "obvious" methodological rules, or because they unwittingly broke them. (14)

In short, creative imagination is key. As Michael Karlberg puts it: "Many of the greatest advances in science required major leaps of imagination combined with an intuitive attraction to the beauty and elegance of compelling ideas" (Constructing Social Reality).

Religion and science also both use representational techniques, such as metaphors or models, to make sense of what they investigate. In science, models are often mathematical, but they also take different forms, a famous example being Niels Bohr's solar system model of the atom. ${ }^{15}$ In religion,

15 One debate is whether such models represent aspects of the world as they we grapple with intelligible realities as well, such as love, happiness, and knowledge. In so doing, we are able to expound these realities only in sensible terms, employing metaphors as we do so. 'Abdu'l-Bahá explains that "when you undertake to express these intelligible realities, you have no recourse but to cast them in the mould of the sensible" (Some Answered Questions 16:4). For example, "knowledge is figuratively described as light, and ignorance as darkness" (16:5).

\section{Faith}

It can additionally be argued that both science and religion are ultimately grounded in faith. Some may take issue with this claim, arguing that science vindicates itself because it works. But there are a few points here.

In the first place, and returning once again to physics, it is certainly true that relativity theory and quantum mechanics are highly effective-they work well. Nevertheless, the quest to find a unifying theory continues, motivated by the underlying assumption that reality is ultimately amenable to being encapsulated by such a theory. The very notion that the universe is interconnected and has a nomological character to it that can be expressed in scientific terms is a matter of faith. ${ }^{16}$

are in themselves, or are just useful fictions for grappling with the phenomena perceived. See, for example, Smith and Karlberg's article as it relates the issue of truth and relativism.

16 Put otherwise, "there is no way to prove logically or show irrefutably through 
No empirical test or observational vantage point could ever infallibly verify such an assumption. The same holds for the ontological claim that science typically rests on - namely, metaphysical naturalism. Although there is some variation in what this means, it is generally understood to be the conviction that nothing exists beyond the natural world and that it is this world, the elements that comprise it, and how these elements relate to each other, that science studies. Yet, ironically, naturalism cannot logically stand without invariably relying on that which is external to it, no matter how well it may seem to work for any given period. That is, on what grounds does it justify its own metaphysical stance without, in the last analysis, resorting either to circular reasoning (i.e., assuming that which it sets out to prove) or to faith?

In the second place, science has come up with a number of laws that appear to accurately explain various facets of reality. But faith remains a factor here as well. Perhaps the most vexing reason is David Hume's problem of induction, which has never been adequately solved. That is, just because some laws appear to work now, and also appear to have repeatedly worked in the past, does not guarantee that they will continue to work in the future. No number of past instances of a law having worked justifies the conclusion on either rational or empirical grounds that the same law will always work.

observation and experimentation the truth of such a premise" (Arbab, "Inquiry"148).
That we assume it will forever hold is again a matter of faith (or of custom or habit); things could always turn out to be otherwise. Referencing Hume once again: that the sun has always risen since the formation of the earth does nothing to guarantee that it will rise again tomorrow.

And in the third place, science is naturally disposed to outdoing itself, so seemingly inviolable scientific theories are always at risk of being superseded by new ones that are-at least potentially-more accurate and more comprehensive in scope. Newtonian physics, which dominated the intellectual landscape for well over two hundred years until Albert Einstein published his famous papers on special and general relativity, is a clear case in point.

That religion is also grounded in faith is comparatively uncontroversial. That, from a Bahá'í perspective, God is one, reality is one, and humanity is inherently one, are all matters of faith. What is important to consider, however, is what it means to have faith. Namely, matters of faith can be held dogmatically, leading, for example, to prejudice, superstition, or fanaticismin which case they are not truly matters of faith, as discussed towards the end of this paper; or they can be held with reflective certitude such that as they are, to the extent possible, conscientiously put into practice and systematically tested in the phenomenal world, understanding of them evolves. ${ }^{17}$ As

17 Further inquiry into this subject might suggest that there is actually a 
William James observes in his essay "The Will to Believe," it is only by acting in accordance with a belief that we can comprehend its benefits and veracity. This point is addressed more fully later when we consider how science cultivates the development of religion. But first it is helpful to turn to some of the ways in which religion cultivates the development of science.

\section{Proposition 3:}

Religion Cultivates the

Development of ScIEnce

In a letter written on its behalf, the House of Justice states "that the task of humanity . . . is to create a global civilization which embodies both the spiritual and material dimensions of existence" and that "[t]he prosecution of this vast enterprise will depend on a progressive interaction between the truths and principles of religion and the discoveries and insights of scientific inquiry" (19 May 1995). This section considers a number of ways in which the truths and principles of religion can be understood to interact with the discoveries and insights of science. The main thesis is that religion as described above cultivates the scientific process, which also means that religion facilitates it, fortifies it, helps to guide it, and opens it up to new possibilities that may otherwise be concealed by materialist or naturalist assumptions. To make this case,

continuum between dogmatism and true faith. this section discusses three subpropositions and outlines some proposed implications that follow. The subpropositions are that religion cultivates science by A) furnishing science with enabling ontological assumptions, B) impelling the development of scientific consciousness, and C) fostering effective collaboration grounded in true friendship.

\section{Subproposition A: Religion Furnish- es Science with Enabling Ontological Assumptions}

Gadamer made the seemingly disconcerting claim that we cannot read reality, understand a text, or interact with another person without prejudice. However, he does not use "prejudice" in the negative sense to which we have become accustomed. Basically, his position is that when we engage with a text, or with an aspect of reality, or in a conversation with someone, we should acknowledge that it is impossible for us to do so without our presuppositions exerting their influence over the way we perceive. We never approach or interact with anything or anyone as blank slates. Rather, preconceptions both enable and constrain our understandings of what we encounter. They can certainly be detrimental: history is fraught with horrific examples of prejudice in action, as is the present. Alternatively, they can be beneficial, attuning us to certain aspects of reality. The point, in any case, is to continually challenge our preconceptions during our encounters, and to adopt and refine assumptions that enable us to achieve 
more accurate and fruitful readings of reality.

It is proposed that this is one of the ways in which religion, as described above, can cultivate the process of scientific discovery. Specifically, it can furnish science with certain vital ontological assumptions without which science can go awry and arrive at conclusions that are not only untethered to reality but are actually harmful. One could reasonably ask, for example, whether or not the so-called "disease" known as hysteria, historically associated with women's wombs and their sexuality, and later with their psychology, would have ever been "discovered" had women been understood to be equal with men at the time. Instead, this seems like a clear case in which science has distorted reality, having socially constructed a disease out of a cluster of symptoms women manifested as a way to cope with their oppressive social circumstances. Remove the patriarchy, and the cluster of symptoms evaporates. In any event, there is no such disease actually "out there" to be discovered (Smith 221-36). Another case is drapetomania, a "disease" identified in the 1850 s to explain the phenomenon of slaves running away from their masters - as if it were natural for them to want to be slaves (289). Obviously, this "disease" does not exist in reality; it is instead nothing more than a social construct divorced from the recognition that ontologically humanity is one.
Subproposition B: Religion Impels the Development of Scientific Consciousness $^{18}$

There are several ways in which it can be proposed to do so, among which are the following.

Revelation, the essence of religion, releases the power of scientific investigation. As we have seen, Revelation expands consciousness by endowing the sincere with a "new eye, a new ear, a new heart and a new mind." It also serves, in Bahá'u'lláh's words, "as the key for unlocking the doors of sciences, of arts, of knowledge, of well-being, of prosperity and wealth" (Tablets 96), illuminating, according to the House of Justice, "all areas of human endeavour and all academic disciplines" (Compilation no. 416). Indeed, Bahá'u'lláh affirms that "[a] 11 the wondrous achievements ye now witness are the direct consequences of the Revelation of this Name" (Gleanings 74:1). The suggestion, therefore, is that science is able to flourish because the world is infused with the Revelation of God. It also flourishes on condition that "man's river flow into the mighty sea, and draw from God's ancient source His inspiration" ("Abdu'1-Bahá, Selections 73:2). When we are thus inspired, we find that "nothing whatsoever in the whole universe can be discovered that doth not reflect His splendor" (Bahá'u'lláh, Gleanings 93:1).

18 In One Common Faith, it is stated that Bahá'u'lláh "recast the whole conception of religion as the principal force impelling the development of consciousness" (23). 
There are many examples of scientists who, motivated by the religious impulse, made tremendous advances. Johannes Kepler is one. Convinced that the Copernican system had geometrical rationality, that God wanted to be recognized through the Book of Nature, and that the world manifested Divine purpose, Kepler developed his three laws of planetary motion, one of which was the groundbreaking idea that the planets orbited the sun in ellipses instead of circles (Campbell and Looy, Section 2: Entries). Isaac Newton, whose work is considered by many to be the greatest achievement of any scientific mind, was similarly inspired, claiming the following in his Principia: "This most beautiful system of the sun, planets, and comets could only proceed from the counsel and dominion of an intelligent and powerful Being" (Campbell and Looy). For him, purity of religion and purity of natural philosophy (science) went hand in hand. A case could be made that both Kepler and Newton were galvanized by the notion that "the highest and last end of all learning [is] the recognition of Him Who is the Object of all knowledge" (Bahá'u'lláh, Gleanings 98:4). ${ }^{19}$

19 There are in fact a myriad other examples which deserve attention, including the many scientific advances made under Islam. 'Abdu'l-Bahá states: "How much Islám served and furthered the cause of science!" (Promulgation 347). Even so, this proposition also needs to take into account the legitimate argument that science was only able to advance when freed from the constraints of religious orthodoxy.
Religion expands consciousness beyond instrumental rationality. Positive science, with its emphasis on cause-effect explanations, is often criticized for advancing a one-sided-some would say, distorted-view of nature. Its emphasis is not so much on the "harmony between society and the natural world" (Universal House of Justice, 29 November 2017) as on how the natural world can be understood in quantitative terms and be subjected to manipulation and exploitation. Moreover, when instrumental thinking is extended to human beings, it reduces them to objects to be studied and disciplined, thus alienating them, robbing them of an aspirational and transcendent understanding of life, and sapping human relations of their potential to be sources of mutual uplift. According to Max Weber, this form of rationalization has come to permeate and regulate our lives (Kalberg). It has subordinated basic questions of value to means-ends logic and has consequently produced a world devoid of moral direction, purpose, and mystery. Michel Foucault has similar concerns. He pays particular attention to the human sciences, which, he says, have their origins in the Enlightenment drive to find more rational ways to govern. The primary concern of these sciences is twofold: to survey and manage populations, and to produce efficient, disciplined, normalized individuals.

With such analyses in mind, it might be suggested that what is critical is the irreducibly situated relationship humans have with the world and each 
other, which ideally entails normative, practical, and discursive engagement. Humans are inherently involved participants and relational beings, and religion, the proposition goes, is essential to nourishing these fundamental aspects of our reality. Thus, when religion informs science, reason expands to take account of these aspects. Put another way, with the influence of religion, instrumental, normative, practical, and communicative reason build on and reinforce one another; the concern with quantity is wedded to a concern with quality; and "is the case" and "ought to be the case" become coherently related.

Religion expands consciousness by encouraging teleological and historical thought. As discussed above, science typically focuses on the efficient causes of things (i.e., relations of cause and effect). It thus generally downplays or ignores three of the four causes identified by Aristotle, namely the material cause (what something is made of), the formal cause (what form it takes or is intended to take), and the final cause (what purpose it serves). Of particular note is the final cause, which was basically dismissed as illegitimate with the rise of science and evolutionary theory, and essentially disappeared with the recent collapse of metanarratives. According to Jean-François Lyotard, we have become incredulous towards metanarratives such as the Enlightenment story, which says that humanity progresses towards greater and greater liberty through the use of reason, and G.W.F. Hegel's story of the progressive unfoldment of knowledge and its invariable unification. These, to elaborate on Lyotard's thesis, have ultimately proven deficient at consolidating thinking, framing our approach to reality, and equipping us with a viable sense of direction or purpose. In their stead, "indifferent, disparate, linguistic practices" have proliferated (Schroeder 329). Lyotard thinks this is a positive development, and from the perspective of allowing for diversity of expression, there is definitely some merit to it. But from a Bahá'í perspective, an overarching, unifying narrative- one that also accommodates a diversity of micro-narratives or practices-is essential to human progress. Without it, fragmentation, needless conflict, and suffering will continue to plague humanity.

As the House of Justice affirms in its 2 March 2013 message, Bahá'ís believe in such a narrative: namely, that humanity has purpose; that it is inexorably moving towards the oneness of humankind, the acme of its evolutionary process; that two interactive processes are propelling humanity in this direction - one disintegrative and the other integrative ${ }^{20}$; and that we

20 The process of integration includes developments such as enhanced worldwide communication through the Internet and other technological means, overall increased concern with the application of human rights, and growing global consciousness of the deleterious effects we are having on the environment. The process of disintegration includes misuses of communications technology (such as for 
have a vital role to play in contributing to the forces of integration. In fact, as the House of Justice avers, "Such is the view of history that underlies every endeavour pursued by the Bahá'i community." This view, which also creates space for micro-stories (allowing for a unity in diversity of stories - a substantial topic in its own right), provides the essential historical and ethical context required for justifying the generation of knowledge, for giving direction to the scientific endeavor more specifically, for establishing meaningful goals to be achieved along the continuum of development, and for determining what knowledge is helpful and what is fallacious and/or deleterious. Would, for instance, such a narrative ever countenance the pursuit of eugenics as a legitimate scientific program, or condone the effort to scientifically categorize races according to intelligence? Similar questions can also be asked regarding technological innovation. ${ }^{21}$

Also deserving attention is the idea that various scientific theories would be enriched by considering the role of final causes. There is, for instance, much to be said on this topic as it pertains to the theory of evolution or to cosmology. ${ }^{22}$

spreading harmful propaganda), growing factionalism and tribalism, the decline of institutional norms and values, and the willful distortion of truth for personal and partisan gain.

21 Weinberg ("Technology") provides an insightful discussion in this regard.

22 See, for instance, Mehanian and
Religion expands consciousness by helping science to avoid engaging in unnecessary forms of reductionism. Science can be reductionist in different ways. One way is by embracing the principle of parsimony, associated with Ockham's Razor, which maintains that the simplest of competing theories or explanations (those involving the least number of assumptions or explanatory entities) is usually the correct, or most acceptable, one. Another way, more typically associated with reductionism, is that science explains complex phenomena by breaking them down into their component parts and articulating the interactions between those parts. Yet another way is that science has a tendency to gravitate towards formulas, as is clearly the case in physics.

There is nothing wrong with being reductive under certain circumstances. It is just that, inappropriately applied, the reductionist mindset can blind scientists to phenomena that exist at higher levels of being or functioning. This is Nagel's insight regarding physicalism: "The physical has been so irresistibly attractive, and has so dominated ideas of what there is, that attempts have been made to beat everything into its shape and deny the reality of anything that cannot be so reduced" (View from Nowhere 15). He thus rejects psychophysical reductionism, since mental

Friberg as well as Phelps. It would additionally be fruitful to compare the teachings of the Bahá'í Faith on this matter with the work of thinkers such as Ian G. Barbour, Paul W. Davies, and Michael Denton. See also blog.loomofreality.org 
capacities cannot be "accommodated by the physical conception of objectivity" (15). The reductionist mindset also disregards certain variables that may be pivotal to explaining a given phenomenon in all its complexity, encourages dichotomous thinking in cases where there are in fact no dichotomies, and is unable to grapple with emergent phenomena (which manifest characteristics qualitatively different than their component parts) as well as with what Arbab, referencing Nagel, calls "extended reality" ("Inquiry" 152).

To be sure, not all scientific approaches are equally reductionist. Some, for example, are more concerned with complexity than others - systems theory, chaos theory, and complexity theory among them. The main point is simply that religion helps to attune science to realities it might otherwise miss or even dismiss, and which, in some cases, they could explore together. ${ }^{23}$ For example, the potential implications for addressing the mind-body interaction problem, and for reconceptualizing the relationship between matter and spirit more generally, are significant.

Religion expands consciousness by awakening within us requisite spiritual susceptibilities. One of Martin Heidegger's insights is that our moods disclose the world to us in certain ways, conditioning what we perceive, how we interpret it, what meanings we assign to it, and what seems possible, with anxiety being the preeminent

23 Arbab ("Inquiry") and Lample both address this very topic. mood for understanding our existential situation (Wrathall 30-37). Our dispositions, more generally, affect what can be revealed about reality. It can be posited that, from a Bahá'í perspective, an essential disposition for perceiving reality and generating knowledge is a humble posture of learning in which fellow investigators find joy in each other's accomplishments, seek ways to build on each other's insights, consolidate the resulting knowledge into fuller, more attuned, understandings of reality, and thereby articulate ever-evolving, unified visions of what has been learned, what avenues of enquiry have demonstrable promise, and how these avenues can best be pursued. Such a posture is especially effective when combined with the motivating impulse that religion inculcates along with, as quoted above, the "capacities to love, to forgive, to create, to dare greatly, to overcome prejudice, to sacrifice for the common good and to discipline the impulses of animal instinct," all of which are essential for generating knowledge and human flourishing, as are the qualities of courage and self-sacrifice. This ties in to a third way in which religion cultivates science.

\section{Subproposition C: Religion Fosters Effective Collaboration Grounded in True Friendship}

It is proposed that religion, drawing specifically on the Bahá'í writings, does this by prescribing the process by which effective collaboration can proceed, namely, "a consultative process which, understood as the collective 
investigation of reality, promotes detachment from personal views, gives due importance to valid empirical information, does not raise mere opinion to the status of fact or define truth as the compromise between opposing interest groups" (Universal House of Justice, 2 March 2013). Gadamer, as we have seen, says that while we can only understand by virtue of our preconceptions, they need not determine the outcome of our understanding. Understanding, in fact, requires work. It necessitates care, perceptiveness, imagination, and, above all, a willingness to put our own preconceptions on trial. This is facilitated by consultation, which presumes that the generation of knowledge is something everyone can and should be empowered to participate in (which, in turn, is in line with the principle of the independent investigation of truth); that insights are provisional and fallible no matter what their human source, but that they are also potentially viable and worthy of consideration; that different viewpoints offer different takes on reality, some of which overlap and reinforce one another; and that a major objective is to collectively scrutinize the value of these perspectives, to weed out the ones that are flawed, and to, where possible, correlate the ones that are beneficial. The overriding concern involves achieving unity of understanding about the truth and strengthening collective purpose rather than having certain opinions win the day. ${ }^{24}$
Furthermore, to facilitate such an exchange of insights, participants endeavor to share their ideas freely but with care, courtesy, devotion, moderation, and humility, and to be detached from their personal views when considering the opinions of others. This approach mirrors one of Michelle Le Doeuff's concerns. For her, as explained by William R. Schroeder, "philosophers must present their ideas with greater humility, as suggestions to be developed rather than closed systems that must either be accepted or rejected in their entirety" (319). Bahá'u'lláh, moreover, links such humility with power:

They who are the beloved of God, in whatever place they gather and whomsoever they may meet, must evince, in their attitude towards God, and in the manner of their celebration of His praise and glory, such humility and submissiveness that every atom of the dust beneath their feet may attest the depth of their devotion. The conversation carried by these holy souls should be informed with such power that these same atoms of dust will be thrilled by its influence. (Gleanings 5:2)

Through such communication, the

about how this approach correlates with, and differs from, other approaches to fostering meaningful dialogue. Key thinkers in this regard include Hannah Arendt, David Bohm, Jurgen Habermas, and Jonathan Haidt. 
walls of misunderstanding dissolve, and agreement about what is the case, what should be the case, and how to work towards the latter in a mutually beneficial manner is facilitated.

\section{Proposed Implications}

There are a number of potentially advantageous implications that stem from the notion that religion cultivates science in the ways discussed above. Specifically, it is suggested that the influence of religion on science helps resolve various issues that have been identified regarding how science actually works and which have not been adequately addressed from a materialist perspective - or, for that matter, from any other philosophical perspective. Briefly, these include the following problems.

The problem of the theory-ladenness of observation. This is the notion that what we perceive of reality is affected by our theories of it. That is, we cannot help but approach reality through our theoretical lenses, which influence what facts we see (and/or construct), how we organize or categorize these facts, what generalizations we infer from them, and what meanings we assign to them. This situation is related to the idea, as Helen Longino puts it, that background assumptions "can ... lead us to highlight certain aspects of a phenomenon over others, thus determining the way it is described and the kind of data it provides" (216). It is debatable how theory-laden observation actually is,${ }^{25}$ but to whatever extent it is, it would seem judicious, where possible, to have it laden with the right set of assumptions. As suggested above, religion plays a key role in this regard.

The problem of the underdetermination of theories. This problem is directly tied to the problem of theory-ladenness. It is that 1) competing theories can often explain the same set of data, and 2) there is no way, appealing to the data alone, of determining which theory is the correct one. Theory choice is underdetermined by the available evidence. But again, religion, with the assumptions it brings and its ability to expand consciousness, can help. For example, one could theorize that the poor are poor because they are lazy, which many have. ${ }^{26}$ Or one could theorize, based on exactly the same data, that they are poor owing to structural conditions and because they have not been sufficiently accompanied and given the opportunity to build requisite capacities to help surmount their deleterious situation. Religion would suggest that the latter theory is more accurate and should be chosen over the former. It thus helps to serve as an algorithm for theory choice. It bears mentioning, moreover, that the latter theory is also

25 The degree to which our lenses or paradigms affect the way in which reality is perceived and socially constructed is an involved subject. See Smith and Karlberg for a discussion.

26 This example is similar to one found in FUNDAEC's discussion on objectivity in Chapter 3 of its unit on Science, Religion, and Development. 
the more complex of the two, once again calling into question the merits of reductionism in certain cases.

The problem of normal science. Thomas Kuhn explains that scientists are habitually involved in what he calls "normal science," which amounts to puzzle solving. By this he means that the paradigms they operate within set out the rules, standards, and problems to be addressed and that scientists endeavor to solve these problems in accordance with those rules and standards. Normal science is about fitting phenomena into the paradigmatic construct. In the process of so doing, the scientist runs into anomalies, which at first are also viewed as puzzles to be solved. However, over time, some of these anomalies can become irritants, at which point the scientist, faithful to his or her paradigm, will often, as Feyerabend depicts it, "interpret . . . evidence so that it fits [his or her] fanciful ideas, eliminate difficulties by ad hoc procedures, push them aside, or simply refuse to take them seriously" (148). Yet, not all anomalies are successfully assimilated, and, as they accrue, they can lead to crisis and subsequently to a paradigm shift or revolution. There is much debate over the accuracy of Kuhn's characterization of normal and revolutionary science, but it is nonetheless a useful account for appreciating once again the power of religion to cultivate the development of science. Specifically, because of its capacity to expand consciousness and foster effective communication-thereby enabling scientists to investigate truth without being unduly influenced by their preconceptions - the hypothesis is that religion can help with identifying anomalies for what they are, and thus with evaluating the adequacy of any given paradigm for guiding scientific work.

The problem of how long to hold on to a theory. This issue is related to the previous problem. The key question is how long to hold on to a theory in light of countervailing evidence. In other words, since a theory is often inundated by anomalies from the outset, what is a reasonable timeframe for giving it a chance, and when does it become fanatical not to let it go? (For example, after Copernicus laid it out, the heliocentric perspective weathered lots of falsifying evidence for over a hundred years until it was finally vindicated by the work of Galileo, Kepler, and Newton.) A theory can often withstand a lot of anomalies because it is made up of a network of core assumptions, concepts, and hypotheses along with auxiliary assumptions, concepts, and hypotheses, and any seemingly falsifying evidence can be readily attributed to its auxiliary features, which can be sacrificed without compromising its core features. ${ }^{27}$ In some cases, this is advantageous for the generation of knowledge. Often, beneficial theories need time and patience on our part to prove themselves, such as the theory, maintained by Bahá'ís, that capacity building for

27 See Godfrey-Smith's discussions of Quine's holistic theory of testing (30-33) and Lakatos's research programs (103-107). 
service is essential for achieving the transformation of society. In other cases, such as social Darwinism, it would seem counterproductive to hold on to a theory notwithstanding its apparent fertility in its heyday. Again, religion helps to identify theories that are constructive and advisable to pursue regardless of the anomalies that would initially suggest otherwise. Operating in a learning mode in light of religious convictions about, say, the oneness and nobility of humankind, helps with distinguishing between which theories should be jettisoned versus which should be given a chance to (potentially) bear fruit. In the absence of such a mode, theories may either be rejected too quickly or maintained irrationally to suit prejudicial interests, neither of which outcome is favorable to progress. In terms of the latter outcome, the House of Justice states that "bigotry is retrograde and unacceptable in whatever form it chooses to present itself" (20 July 1977).

The problem of incommensurability. This is the idea, stemming from both Kuhn's and Feyerabend's work, that there is no common measure for comparing theories and that their proponents actually talk past each other because they see different realities, employ different methods, recognize different standards, and in fact live in different worlds. Again, there is controversy over whether or not different paradigms truly are incommensurable. In any event, religion can assist here as well. Although not prescriptive of the methods that should be employed across various academic endeavors, it once again provides assumptions and standards that can serve as a basis for intelligible communication between theoretical frameworks. In addition, it establishes consultation as the method for the collective search for truth, instills in the individual requisite spiritual susceptibilities that expand consciousness, and contextualizes all scientific endeavors within a common historical narrative. In these ways and others, religion can help to dissolve paradigmatic walls that may otherwise remain unyielding by facilitating meaningful communication that can in fact lead to the correlation, even synthesis, of initially disparate paradigmatic insights. In so doing, it can help to address a current dilemma identified in a letter written on behalf of the House of Justice:

One of the problems of modern times is the degree to which the different disciplines have become specialized and isolated from one another. Thinkers are now faced with a challenge to achieve a synthesis, or at least a coherent correlation, of the vast amount of knowledge that has been acquired during the past century. (Compilation no. 430)

Proposition 4: Science Cultivates the Development of Religion

According to 'Abdu'l-Bahá:

Bahá'u'lláh declared that religion is in complete harmony with science 
and reason. If religious belief and doctrine is at variance with reason, it proceeds from the limited mind of man and not from God; therefore, it is unworthy of belief and not deserving of attention; the heart finds no rest in it, and real faith is impossible. (Promulgation 231)

Having outlined in the three previous sections some of the proposed ways in which science and religion supplement and correspond to each other, and in which religion cultivates the development of science-keeping in mind the reciprocity between the two systems of knowledge - this final section turns to some of the proposed ways in which science cultivates the development of religion. This section is vital in addressing the concerns raised by critics of religion, because it recognizes that when unnourished by science, religion does indeed become problematic. Four subpropositions are briefly considered, namely, that science cultivates religion by helping to A) refine understanding of its core assumptions, B) identify what is possible for it to achieve, C) ensure that faith does not degenerate into superstition, and D) ensure that religious practice does not become ritualized.

\section{Subproposition A: Science Helps to Refine Our Understanding of the Core Assumptions of Religion}

Shoghi Effendi states that the Bahá'i Faith is "scientific in its method" (Letter). The scientific approach the Bahá'i community is learning about involves a process of action, reflection on action, consultation, and study in which all are invited to participate. As Bahá'ís and their collaborators engage in community-building activities devoted to the spiritual and moral empowerment of children and junior youth, enhancing the devotional life of the community, raising capacity for service, and participating in social and economic development projects as well as in discourses relevant to the advancement of society, they turn to the teachings of the Bahá'i Faith and the guidance of the Universal House of Justice and strive to put these precepts into practice through consistent, systematic action. In so doing, their knowledge is tested, giving rise to insights and questions about which approaches work and what adjustments need to be made to more fruitfully advance their various endeavors. Through reflection and consultation on such experience in light of further study of the teachings and the continuous flow of guidance from the House of Justice, new levels of understanding are achieved on how best to proceed, which are again tested in action.

This reciprocal, organic process gives rise to ever-advancing emergent conditions, which enables both the community and the individuals that compose it to progressively flourish as generators of knowledge and servants of humanity. At the same time, the proposition is that this learning mode inspires further insights into the nature of the core tenets of the Bahá'í Faith-into, for 
example, what is meant by the oneness of humanity, the inherent nobility of every human being, the capacity of people to contribute to the accumulation of knowledge, and the equality of women and men. While, on the one hand, such assumptions will never be abandoned, our understanding of them is subject to change as we put them into practice and then reflect on the experience gained. This, it is further proposed, is part of what it means to combine an unshakable confidence in the core principles of religion with a posture of humility. While, again, our belief in the equality of women and men will always remain core, we cannot be dogmatic about our understanding of this fundamental tenet because our understanding is always subject to refinement through the scientific approach we have adopted.

\section{Subproposition B: Science Helps to Identify What Is Possible for Religion to Achieve in Any Given Setting}

Science helps to determine what the situation is, what works and does not work, and what is possible. As religion cultivates science by furnishing it with enabling ontological assumptions, expanding consciousness, and channeling the power of Divine assistance, science in turn helps religion to avoid unwarranted idealism by providing tools with which to read reality, to assess capacity, and to either corroborate or falsify certain hypotheses about what can be achieved under particular circumstances. Reality both enables and constrains what is possible in any given setting, and science helps religion to be attuned to this.

The scientific approach to achieving such attunement involves various elements of systematization at the community level, such as developing unity of understanding about current conditions as well as unity of vision about viable possibilities for growth; devising, in accordance with such vision, concrete goals and plans of action to meet those goals based on what has been accomplished to date as well as on realistic assessments of capacity, resources available, and the coherence of different endeavors; faithfully implementing those plans in a spirit of harmony; making necessary adjustments to plans as experience is gained, albeit in a manner that does not compromise continuity of action; analyzing the knowledge that has thus accrued; and revising visions of growth in view of this knowledge, the increased capacity developed, the greater level of coherence between the different endeavors being pursued, and the new opportunities created as a result of this process. Overall, this scientific approach is concerned with "how the capacities and powers of the human spirit can be tangibly channeled to effect beneficial social change" (Weinberg, "Contributions" 209). It is, moreover, an organic process that encourages the community to be neither haphazard nor rigid, neither frenetic nor formulaic, in its approach to applying religious teachings and generating beneficial knowledge. ${ }^{28}$

28 This summary of systematization 
Subproposition C: Science Helps to Ensure that Faith Does Not Degenerate into Superstition

This is a core claim of the Bahá'í Faith. 'Abdu'l-Bahá states: "If religion does not agree with science, it is superstition and ignorance" (Promulgation 128). On this point, it is helpful to distinguish between superstition and faith. It is proposed that superstitions are beliefs or practices, typically about the perceived supernatural, that are uninformed by reason or systematic investigation. They are fictitious reifications socially constructed as means for dealing with ambiguity or fear of the unknown. Because they are practiced unreflectively, they are essentially mechanical and dogmatic. Faith, on the other hand, is equivalent to "conscious knowledge expressed in action" (Universal House of Justice, Turning Point 294). It is anything but blind acceptance.

As we have seen, every theory or assumption, whether scientific or religious, is in the last analysis based on some element of faith. However, as we have also seen, faith evolves through the scientific process of action, reflection on action, and consultation, conducted with systematic reference to authoritative guidance. It is tested through observation, experimentation, and reason. This seems to be the crux of the matter. Without such a learning process in place, statements of faith can

draws on the 27 December 2005 and 28 December 2010 messages of the Universal House of Justice, as well as on its statement The Institution of the Counsellors. easily become ossified, and it is only a short step from ossification to superstition. It is also only a short step from ossification to the imposition of ideas by those with more sway, thus compromising the essential principle of the independent investigation of truth.

In short, faith as opposed to superstition is characterized by a mode of learning which entails comfort with ambiguity, willingness to modify understanding in view of experience, reflective certitude versus unreflective certainty, and processual versus formulaic thinking. Informed as it is by scientific methods, faith expands consciousness, whereas superstition stifles it, blinding it to certain realities and possibilities for growth. ${ }^{29}$

\section{Subproposition D: Science Helps to Ensure that Religious Practice Does Not Degenerate into Ritual}

Similarly, this scientific mode of learning helps to guard against ritual and rigidity in the application of religious teachings. Avoiding ritual is essential for promoting an animated unity as opposed to discord and superficiality. On this point, 'Abdu'l-Bahá states: “All these divisions we see on all sides, all these disputes and opposition, are caused because men cling to ritual and outward observances, and forget the simple, underlying truth" (Paris Talks

29 Comparisons could be also made with ideology, whether religious or secular, although the discussion would be more involved as ideology is typically more comprehensive and systematic than superstition. 
39:12). Operating in a mode of action, reflection on action, consultation, and study assists with determining what a given religious activity or practice is for, how effective it is at meeting its stated objective(s), and how, where appropriate, it can be continually improved upon so that it does not become divisive, formulaic, hollow, or stale.

\section{Conclusion}

The House of Justice affirms that "religion without science soon degenerates into superstition and fanaticism, while science without religion becomes the tool of crude materialism" (2 March 2013). Neither religion nor science can realize its true potential when there is no reciprocity between them. Each on its own invariably lapses into dogmatism and sterility, or becomes far less than it can be, which in turn leads to fragmentation, disenchantment, mediocrity, alienation, anomie, and the hampering of humanity's progress towards oneness. When, on the other hand, they are in dynamic interplay, they both evolve into what they can truly be, thereby achieving that which is far greater than the sum of what each can bring about on its own.

This paper has proposed one approach to articulating the complementarity between science and religion - in view of the legitimate concerns that many proponents of materialism and other thinkers have about religion and the ills of society - which is to consider how these two systems of knowledge and practice supplement, correspond to, and cultivate each other. It is suggested that by adopting such an approach, and by subjecting the various propositions and subpropositions advanced in this paper to further scrutiny, we can more adequately understand how science and religion, in their true forms, engage in a unity in diversity of knowledge generation that is essential for the progress of humanity.

In making this case, the paper has introduced a number of concepts and ideas, all of which deserve much greater attention than has been possible here. Future areas of exploration could also include how the dynamic relationship between science and religion helps to resolve additional issues of perennial concern such as the perceived tensions between objectivity and subjectivity, foundationalism and anti-foundationalism, and truth and relativity. Finally, the Báb admonishes us to "observe all the things which God hath created at His behest with the eye of the spirit, even as ye see things with the eyes of your bodies" (Selections 17:15), enabling us to, as Bahá'u'lláh states, "discriminate between truth and falsehood, even as [we] distinguish the sun from shadow" (Gleanings 125:7). It would seem propitious, therefore, to place greater emphasis on exploring the power of spiritual discernment to advance both systems of knowledge and practice. 


\section{Works CITED}

‘Abdu'l-Bahá. Paris Talks. Nine Pines Publishing, 1995.

__ - The Promulgation of Universal Peace. Bahá'í Publishing Trust, 1982.

__ - Selections from the Writings of 'Abdu'l-Bahá. Bahá'í Publishing Trust, 1997.

——. Some Answered Questions. Bahá'í World Centre, 2014.

__ . Tablet to Auguste Forel. Bahá'i Reference Library, www.bahai.org/r/690115704.

Arbab, Farzam. "An Inquiry into the Harmony of Science and Religion." Religion and Public Discourse in an Age of Transition: Reflections on Bahá'i Practice and Thought, edited by Geoffrey Cameron and Benjamin Schewel. Association for Bahá'í Studies and Wilfrid Laurier UP, 2017, pp. $131-62$.

. "The Intellectual Life of the Community." Journal of Bahá'i Studies, vol. 26, no. 4, 2016, pp. 9-21.

Arendt, Hannah. The Portable Hannah Arendt. Edited by Peter Baehr, Penguin Books, 2000.

Aristotle. The Basic Works of Aristotle. Edited by Richard McKeon, Modern Library, 2001.

Axelrod, Robert. The Evolution of Cooperation. Basic Books, 2006.

The Báb. Selections from the Writings of the Báb. Bahá'í World Centre, 1976.

Bahá'í International Community Office of Public Information. A Statement on Bahá 'u'lláh. Bahá'í Canada Publications, 1991.

Bahá'u'lláh. Gleanings from the Writings of Bahá u'lláh. Translated by Shoghi Effendi, Bahá'í Publishing Trust, 1976.

___ The Kitáb-i-Íqán: The Book of Certitude. Translated by Shoghi Effendi, Bahá’í Publishing Trust, 2019.

___ Tablets of Bahá 'u'lláh Revealed after the Kitáb-i-Aqdas. Bahá'í Publishing Trust, 1988.

Barbour, Ian G. Religion and Science: Historical and Contemporary Issues. HarperOne, 1997.

Beck, Ulrich. Risk Society: Towards a New Modernity. Sage Publications, 2009.

Berger, Peter. The Sacred Canopy: Elements of a Sociological Theory of Religion. Anchor Books, 1990.

Bohm, David. On Dialogue. Routledge, 1996.

Campbell, Heidi A., and Heather Looy. A Science and Religion Primer. E-book, Baker Academic, 2009.

The Compilation of Compilations. Vol. 3, Bahá'í Publications Australia, 2000.

Coyne, Jerry A. Faith vs. Fact: Why Science and Religion Are Incompatible. Penguin Books, 2015. 
Davies, Paul W. God and the New Physics. Penguin, 1983.

Dawkins, Richard. The God Delusion. Mariner Books, 2008.

Dennett, Daniel C. Breaking the Spell: Religion as a Natural Phenomenon. Viking Adult (Penguin), 2006.

Denton, Michael J. Nature's Destiny: How the Laws of Biology Reveal Purpose in the Universe. Free Press, 1998.

Falk, Dan. Universe on a T-Shirt: The Quest for the Theory of Everything. Arcade Publishing, 2013.

Farid-Arbab, Sona. Moral Empowerment: In Quest of a Pedagogy. Bahá'i Publishing, 2016.

Feuerbach, Ludwig. The Essence of Christianity. Translated by George Eliot, Prometheus Books, 1989.

Feyerabend, Paul. Against Method. 3rd ed., Verso, 1993.

Foucault, Michel. Power/Knowledge: Selected Interviews and Other Writings, 1972-1977. Edited by Colin Gordon, Pantheon Books, 1980.

FUNDAEC. Science, Religion, and Development. Fundación para la Aplicación y Enseñanza de las Ciencias, 2005.

Gadamer, Hans-Georg. Truth and Method. Bloomsbury, 2013.

Geuss, Raymond. "Nietzsche: The Birth of Tragedy." Introductions to Nietzsche, edited by Robert B. Pippin, Cambridge UP, 2012, pp. 44-66.

Godfrey-Smith, Peter. Theory and Reality: An Introduction to the Philosophy of Science. U Chicago P, 2003.

Gregg, Samuel. Reason, Faith, and the Struggle for Western Civilization. Gateway Editions, 2019.

Habermas, Jurgen. Philosophical Introductions: Five Approaches to Communicative Reason. Polity Press, 2018.

Haidt, Jonathan. The Righteous Mind: Why Good People Are Divided by Politics and Religion. Vintage Books, 2012.

Hanley, Paul. Eleven. Friesen Press, 2014.

Harrison, Peter. The Territories of Science. U Chicago P, 2017.

Haught, John. A John Haught Reader: Essential Writings on Science and Faith. Wipf \& Stock, 2018.

Henrich, Natalie, and Joseph Henrich. Why Humans Cooperate: A Cultural and Evolutionary Explanation. Oxford UP, 2007.

Hitchens, Christopher. God Is Not Great: How Religion Poisons Everything. McClelland \& Stewart, 2008.

Hume, David. A Treatise of Human Nature. Edited by L.A. Selby-Bigge and P.H. Nidditch, Oxford UP, 1978.

James, William. Pragmatism and Other Writings. Penguin Classics, 2000.

Kalberg, Stephen. "Max Weber." The Blackwell Companion to Major Classical Social Theorists, edited by George Ritzer, Blackwell, 2003, pp. 132-92. 
Karlberg, Michael. Constructing Social Reality: An Inquiry into the Normative Foundations of Social Change (working title). Association for Bahá'í Studies, forthcoming.

. Beyond the Culture of Contest. George Ronald, 2004.

Kierkegaard, Soren. The Essential Kierkegaard. Edited by Howard V. Hong and Edna H. Hong, Princeton UP, 2000.

Klein, Naomi. No Logo. 10th anniversary ed., Picador, 2009.

Kuhn, Thomas S. The Structure of Scientific Revolutions. U Chicago P, 1970.

Lample, Paul. "In Pursuit of Harmony between Science and Religion." Journal of Bahá'i Studies, vol. 26, no. 4, 2016, pp. 25-58.

doi: 10.31581/JBS-26.4.4(2016)

Longino, Helen E. Science as Social Knowledge: Values and Objectivity in Scientific Inquiry. Princeton UP, 1990.

Lyotard, Jean-François. The Postmodern Condition: A Report on Knowledge. U Minnesota P, 1993.

Marcuse, Herbert. One-Dimensional Man: Studies in the Ideology of Advanced Industrial Society. 2nd ed., Beacon Press, 1991.

Marx, Karl. The Portable Karl Marx. Edited by Eugene Kamenka, Penguin Books, 1983.

McGrath, Alister E. The Territories of Human Reason: Science and Theology in an Age of Multiple Rationalities. Oxford UP, 2019.

Mehanian, Courosh, and Stephen R. Friberg. "Religion and Evolution Reconciled: 'Abdu'l-Bahá's Comments on Evolution.” Journal of Bahá'i Studies, vol. 13, no. 1/4, 2003, pp. 55-93. doi: 10.31581/JBS-13.1-4.3(2003)

Mishra, Pankaj. Age of Anger: A History of the Present. Farrar, Straus and Giroux, 2017.

Murphy, Nancy. A Philosophy of the Christian Religion: For the Twenty-First Century. SPCK Publishing, 2018.

Naess, Arne. The Ecology of Wisdom. Edited by Alan Drengson and Bill Devall, Counterpoint, 2008.

Nagel, Thomas. The Possibility of Altruism. Princeton UP, 1970.

The View from Nowhere. Oxford UP, 1986.

Nietzsche, Friedrich. The Portable Nietzsche. Edited and translated by Walter Kaufmann, Penguin Books, 1982.

___ Thus Spoke Zarathustra. Translated by R. J. Hollingdale, Penguin Books, 1969.

Norberg, Johan. Progress: Ten Reasons to Look Forward to the Future. Oneworld Publications, 2017.

Nowak, Martin A. Super Cooperators: Altruism, Evolution, and Why We Need Each Other to Succeed. Free Press, 2012.

One Common Faith. Commissioned by the Universal House of Justice, 2005. 
Phelps, Steven. "Perspective: Crossing the Divide between Science and Religion: A View on Evolution." One Country, April-June 2008. www.onecountry. org/story/perspective-crossing-divide-between-science-and-religionview-evolution

Pinker, Steven. Enlightenment Now: The Case for Reason, Science, Humanism, and Progress. Penguin Books, 2018.

Polkinghorne, John. Science and Religion in Quest of Truth. SPCK Publishing, 2011.

Rosling, Hans, with Ola Rosling and Anna Rosling Rönnlund. Factfulness: Ten Reasons We're Wrong about the World - and Why Things Are Better than You Think. Flatiron Books, 2018.

Rovelli, Carlo. Seven Brief Lessons on Physics. Riverhead Books, 2016.

Rushdie, Salman. "'Imagine There's No Heaven': A Letter to the Six Billionth World Citizen." The Portable Atheist: Essential Readings for the Nonbeliever, selected and with introductions by Christopher Hitchens, Da Capo Press, 2007, pp. 380-383.

Sacks, Jonathan. The Great Partnership: Science, Religion, and the Search for Meaning. E-book, Schocken, 2014.

Schewel, Benjamin. Seven Ways of Looking at Religion: The Major Narratives. Yale UP, 2017.

Schroeder, William R. Continental Philosophy: A Critical Approach. Blackwell Publishing, 2005.

Shoghi Effendi. Letter to the High Commissioner for Palestine. June 1933. . The World Order of Bahá 'u'lláh. US Bahá'í Publishing Trust, 1991.

Simmel, Georg. On Individuality and Social Forms: Selected Writings. Edited by Donald N. Levine, U Chicago P, 1971.

Smith, Todd, and Michael Karlberg. "Articulating a Consultative Epistemology: Toward a Reconciliation of Truth and Relativism." Journal of Bahá' $i$ Studies, vol. 19, no. 1/4, 2009, pp. 59-99. doi: 10.31581/JBS-19.14.3(2009)

Smith, Todd. The Relativity of Social Construction: Towards a Consultative Approach to Understanding Health, Illness, and Disease. 1997. University of Toronto, PhD dissertation.

Taylor, Bonnie J., and John Hatcher, editors. One Reality: The Harmony of Science and Religion. Bahá'í Publishing, 2013.

Taylor, Charles. The Malaise of Modernity. House of Anansi Press, 1998.

The Universal House of Justice. The Institution of the Counsellors. Bahá'i World Centre, 2001.

_— Letter written on its behalf to an individual, 20 July 1977.

___ Letter written on its behalf to an individual, 19 May 1995. Bahá'í Reference Library, www.bahai.org/r/714818738. 
___ Letter to the world's religious leaders, April 2002. Bahá'i Reference Library, www.bahai.org/r/024035169.

___ Letter written on its behalf to the Bahá'ís of Iran, 2 March 2013. Bahá'í Reference Library, www.bahai.org/r/063389421.

___ L L Letter written on its behalf to three individuals, 29 November 2017. Bahá'i Reference Library, www.bahai.org/r/665166280.

___ Message to the peoples of the world, October 1985. Bahá'i Reference Library, www.bahai.org/r/883867984.

___ Message to the Bahá'ís of the world, Riḍván 1999. Bahá'i Reference Library, www.bahai.org/r/104279438.

__ - Message to the Conference of the Continental Boards of Counsellors, 27 December 2005. Bahá'i Reference Library, www.bahai. org $/ \mathrm{r} / 527522699$.

_- Message to the Conference of the Continental Boards of Counsellors, 28 December 2010. Bahá'í Reference Library, www.bahai.org/r/418566551.

___ Message to the Bahá'ís of the world, Rị̣ván 2012. Bahá'i Reference Library, www.bahai.org/r/418566551.

___ _ Turning Point: Selected Messages of the Universal House of Justice and Supplementary Material 1996-2006. Palabra Publications, 2006.

Weinberg, Matt. “Contributions to International Development Discourse: Exploring the Roles of Science and Religion." Religion and Public Discourse in an Age of Transition: Reflections on Bahá'i Practice and Thought, edited by Geoffrey Cameron and Benjamin Schewel, Wilfrid Laurier UP, 2017, pp. 191-219.

__ _ "Technology, Values, and the Shaping of Social Reality." The Baha' $i$ World, bahaiworld.bahai.org/articles/technology-values-shaping-socialreality.

Wrathall, Mark. How to Read Heidegger. Granta Books, 2014. 